\title{
Even terugkijken
}

H. van den Broek

Wij realiseren ons zelden dat we in een fantastische tijd leven. Nog nooit hebben in het bestaan van de mens in zo korte tijd zoveel revolutionaire veranderingen ons leven gewijzigd. Als radioloog heb ik daarvan de afgelopen 30 jaar op medisch gebied van nabij een bevoorrecht getuige mogen zijn.

\section{De revolutie vanaf 1980}

Tijdens mijn coassistentschap in 1974 presteerde een twintigjarige patiënt het om na zes weken nog steeds in bed te liggen na een ouderwetse meniscusoperatie. In 1980 werd een galsteen zoals gebruikelijk verwijderd met een grote klassieke snee in de buik. Voor een niet genezende maagzweer werd een stuk maag afgeknipt, na een hartinfarct moest je twee en liefst zes weken stil in bed liggen en een aneurysmatisch bloedvatgezwel in de hersenen werd geopereerd door de schedel te openen.

Amper 10 tot 15 jaar later werden zowel meniscus als galstenen via de scoop verwijderd, maagzweren verdwenen als sneeuw voor de zon dankzij de nieuwe maagzuurremmers en antibiotica, bij hartinfarcten werden stolsels in de hartvaten medicamenteus opgelost en vernauwingen gedotterd en de hersenaneurysma's werden via de lies van binnenuit het bloedvat gecoiled. Voor nierstenen werd vergruizing een onverwacht nieuw hulpmiddel. En bij dat alles was de patiënt vele malen sneller thuis.

\section{Koorts door infecties}

Gefascineerd door al die ontwikkelingen begon ik terug te kijken naar de situatie waar we uit voortgekomen zijn: In 1900 was de gemiddelde leeftijd voor een vrouw 45 jaar en voor een man 50 . Toch zeggen die getallen niet alles want ik kan een hele reeks honderdjarigen uit de afgelopen eeuwen aanleveren. Je moest blijkbaar een beetje geluk hebben om oud te kunnen worden. Bij mijn naspeuringen bleek al snel dat twee belangrijke elementen telkens weer opdoken die bepaalden of je dóórleefde of overleed: infectieziektes en onvoldoende of kwalitatief slecht voedsel. Kort gezegd 'Koorts en Honger'.

Het is onvoorstelbaar dat veel exotisch klinkende ziektes die door ons nu niet meer meteen herkend zouden worden, hier endemisch waren zoals lepra (melaatsheid), pest (de gave Gods), pokken (de kinderziekte), cholera (krijg de klere), bacillaire dysenterie (de rode loop), tyfus, difterie, malaria (de vierde daagse ziekte), tetanus (klemmond) en natuurlijk tuberculose. Het waren ziektes waarbij de sterksten, of beter gezegd de gelukkigen met het juiste afweersysteem of voedseltoestand, het overleefden. Daarnaast had menigeen last van luizen of wormen maar dat was maar zelden een dodelijke besmetting.

De methodes: sappen - sympathie - signatuur - sinten - slechterikken - sijfers

De medici behandelden dit soort aandoeningen voornamelijk op basis van op de sappenleer gebaseerde opvattingen. Als de verhouding tussen de vier lichaamssappen (gele gal, zwarte gal, bloed of slijm) verstoord was dan moest dit in evenwicht gebracht worden. Hiervoor was in de loop 
der eeuwen een uitgebreid arsenaal ter beschikking gekomen. Men paste aderlaten toe, zette bloedzuigers op, gaf niesmiddelen, schoor haar af, liet mensen zweten of kwijlen, gaf laxeer-, braak- of plasmiddelen en schreef voor wie het betalen kon een dure optie voor als het naar bed gaan met jonge maagden.

Daarnaast floreerden methodes als de sympathieleer, te vertalen als tovergenezing op afstand, de hemel aanroepende of de duivel uitdrijvende handelingen, de signatuurleer [wat er op lijkt dat helpt] en ten slotte bij veel middelen het magisch gebruik van getallen.

De beschikbare kruiden werden meestal toegepast binnen het kader van de zojuist genoemde signatuurleer. Zo gaf men rode bloempjes bij bloederige diarree, longkruid bij longziektes en stinkende gouwe met haar oranje-gele sap bij leverziektes. Opmerkelijk is trouwens dat veel toenmalige plantaardige geneesmiddelen thans als kruiden in het keukenkastje beland zijn zoals peper, kaneel, koriander, kruidnagel, nootmuskaat, zoethout, gember en saffraan.

\section{Het voedsel}

Als we kijken naar datgene wat de boeren verbouwden, dan blijkt dat ze overwegend rogge produceerden en daar waar dit uitkwam boekweit en tarwe. Pas na 1740 kwam de aardappel op grote schaal ter beschikking. Die leverde een extra, zeer welkome bron van energie. En vitamine C. Hoewel moeilijk herkenbaar, komen via onverwachte bronnen telkens tipjes van vitaminetekorten in beeld. Met name in wonderverhalen waarvan ik er thans 2500 geanalyseerd heb. Zo vinden we voorbeelden van een tekort aan vitamine A bij kinderen die blind worden na een infectie met pokken of mazelen. Na enige tijd genezen de kinderen, dankzij betere voeding (?), weer van hun blindheid. Hetzelfde geldt voor de vele vermeldingen van kinderen die lam zijn vanaf hun geboorte en waarbij de beschrijvingen naadloos passen bij een gebrek aan vitamine D ofwel Engelse ziekte. Beter bekend en beschreven is het gebrek aan vitamine $\mathrm{C}$ dat vooral op lange zeereizen maar ook bij langdurige belegeringen van steden een rol speelde. Zelden beschreven, maar onmiskenbaar is de aanwezigheid van hypothyreoïdie door jodiumgebrek. Zo blijkt in 1950 in zuidoost Brabant 40\% van de pubers een struma te hebben. Als regel zit te weinig jodium in het water dat afkomstig is van de schrale zandgronden.

\section{De gezondheidswerkers}

Daarnaast is het leuk om eens naar de werkers in de gezondheidszorg van die dagen te kijken: chirurgijn, vroedvrouw en 'medicine doctor', bijgestaan door kruidenvrouwtjes en soms door brandvrouwtjes. Op jaarmarkten kwamen daar nog staarstekers, steen- en breuksnijders, tandentrekkers en last but not least kwakzalvers bij.

Langzaam zien we vanuit de middeleeuwen de chirurgijns loskomen van het barbiersvak. Heel geleidelijk gaat de beroepsgroep steeds meer eisen aan de nieuwkomers stellen. Via een meester-gezelsysteem, boeken en rondreizende vakgenoten neemt de kennis en algemene ervaring toe. Bij de vroedvrouwen daalt de kennis echter telkens weer naar een zeer basaal niveau en is beperkt tot de plaatselijk meest ervaren vrouw. Meestal is dat de vroedvrouw die meerdere kinderen met succes gebaard heeft en eventueel gehuwd is met de chirurgijn. Pas in de negentiende eeuw komt ook hier de opleiding van de grond.

Los daarvan staan de medicine doctores die al vanaf de middeleeuwen universitair worden opgeleid. Voor zover is te achterhalen speelt op het platteland de medicine 
doctor maar een zeer beperkte rol. Hij is er vooral voor diegenen die hem kunnen betalen: de geestelijkheid, hogere ambtenaren en adel. Zijn werk bestaat voor het merendeel in het adviseren van aderlating (door de chirurgijn), recepten en leefregels. Zelden ziet men dat hij actief ingrijpt aan het lichaam zelf.

\section{De auteur:}

Dr. H. van den Broek is als radioloog verbonden aan het Elkerliek Ziekenhuis te Helmond. Hij is al 20 jaar actief met heemkunde en geschiedenis der geneeskunde in de vorm van vele publicaties. Dit jaar verscheen het boek "Koorts en Honger", 472 bladzijdes dik en rijk geillus- treerd. Voor wie geïnteresseerd is en zich verdiepen wil in de geneeskunde van vroeger tijden ligt een fascinerende wereld met veel punten van herkenning en momenten van verbazing te wachten.

Deze uitgave is in eigen beheer en te bestellen via koortsenhonger@hotmail.com voor $€ 29,50$. De baten gaan naar projecten die infecties en ondervoeding bestrijden.

Correspondentieadres:

Dr. H. van den Broek;

e-mail:koortsenhonger@hotmail.com

Belangenconflict: geen gemeld

Financiële ondersteuning: geen gemeld

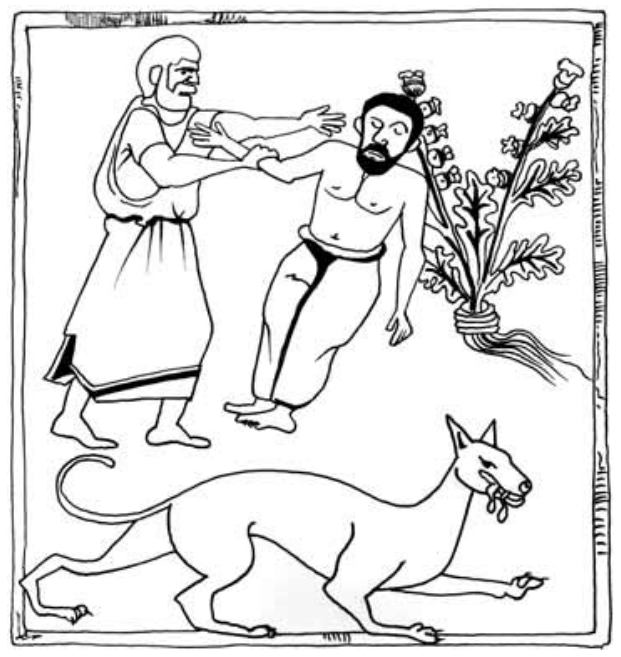

Afbeelding 1. Bilzenkruid helpt tegen hondsdolheid* * illustrator Kees Combee

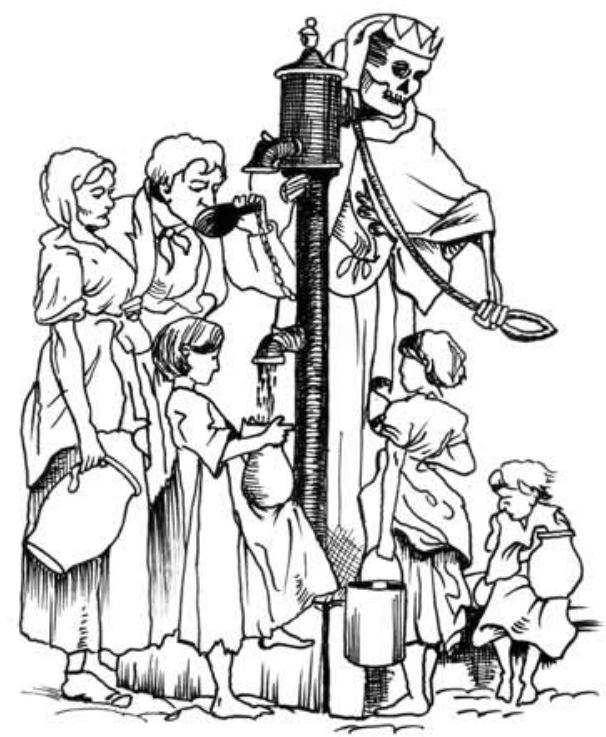

Afbeelding 2. Cholera: de dood komt uit de kraan* 